\title{
Diosgenin Quantification by HPLC in a Dioscorea polygonoides Tuber Collection from Colombian Flora
}

\author{
Jaime Niño, * Diego A. Jiménez, Oscar M. Mosquera and Yaned M. Correa \\ Grupo de Biotecnología - Productos Naturales, Escuela de Tecnología Química, \\ Universidad Tecnológica de Pereira, La Julita, A.A. 97 Pereira, Colombia
}

\begin{abstract}
As concentrações de diosgenina em uma coleção de tubérculo de Dioscorea polygonoides do Eje Cafetero (EC, Colombia) foram determinadas por cromatografia líquida de alta eficiência. Os teores obtidos variaram de 0,02 a 2,64\%. A maior concentração de diosgenina $(2,64 \%)$ foi obtida de um tubérculo coletado perto de Salento (Quindio). A média de recuperação desta foi de $97 \%$. A identificação foi feita por cromatografia gasosa-espectrometria de massas (CG-EM) e por coeluição com o padrão autentico. Os resultados destes estudos foram importantes uma vez que os teores de diosgenina obtidos se mostraram superiores quando comparados aqueles relatados para outras espécies medicinais de Dioscorea, tornando Dioscorea polygonoides uma fonte potencial de diosgenina.
\end{abstract}

The diosgenin concentrations in a Dioscorea polygonoides tuber collection from the Eje Cafetero (EC, Colombia) were determined by HPLC and their percentages ranged from 0.02 to $2.64 \%$. The highest diosgenin concentration $(2.64 \%)$ was obtained in a tuber collected near Salento (Quindío). The average of diosgenin recovery was $97 \%$. Diosgenin was identified by gas chromatography-mass spectrometry (GC-MS) and by coelution with authentic diosgenin standard in both HPLC and GC-MS techniques. The results of this study are important since comparatively they are higher than most of those reported on other medicinal Dioscorea species, making Dioscorea polygonoides a potential new source of diosgenin.

Keywords: bioprospection, Colombian biodiversity, Dioscorea, diosgenin screening, steroidal sapogenin

\section{Introduction}

The most important families that biosynthesize steroidal saponins are Agavaceae (genus Agave), Dioscoreaceae (genus Dioscorea) and Liliaceae (genera Allium, Asparagus, Lilium). ${ }^{1}$ Yams belong to genus Dioscorea (Dioscoreaceae family) with near 400 species growing in the tropical and subtropical wet areas around the world. This family is characterized by the production of subterranean or aerials tubers. Usually its species are climbing vines and many of them are dioicous. ${ }^{2}$

Several Dioscorea species are economically important as staple food, ${ }^{3,4}$ and others are used for the production of steroidal saponins, which on hydrolysis render sapogenins, such as diosgenin (Figure 1), which is important as starting material for the production of corticosteroids, sexual hormones, oral contraceptives as well as other steroids via hemisynthesis. ${ }^{5-7}$

*e-mail: janino@utp.edu.co
Dioscorea polygonoides Humb. et. Bonpl. ex Willd. belongs to the Dioscoreaceae family, genus Dioscorea, subgenus Eudioscorea and to the section Lynchnostemon, which is well distributed from Mexico to Brazil, crossing by Colombia and the Antilles. ${ }^{2,8}$ From D. polygonoides two steroidal saponins, diospolysaponin A and prosapogenin A of dioscin have been isolated and characterized. The last compound showed cytotoxic activity against the $\mathrm{HSC}-2\left(\mathrm{IC}_{50}\right.$ $3.4 \mu \mathrm{g} \mathrm{mL}^{-1}$ ) cell line which was as potent as the positive control, doxorubicin $\left(\mathrm{IC}_{50} 2.5 \mu \mathrm{g} \mathrm{mL}^{-1}\right){ }^{9}$ In addition, three<smiles>CC1CCC23OCCCC2C(C)C3C2CC3C4CC=C5CC(O)CCC5(C)C4CCC3(C)C2C1C</smiles>

Figure 1. Diosgenin. 
new polyhydroxylated spirostanol saponins were isolated from $D$. polygonoides tubers and their structure determined on the basis of extensive spectroscopic analysis. ${ }^{10}$

To date, diosgenin and related sapogenins are commercially available from tubers of different Dioscorea species; however, recent experimental evidence has showed that diosgenin has proved human health benefit. ${ }^{11}$ These discoveries have increased diosgenin demand world wide and motivated the search for new and renewable sources for this important raw material for the pharmaceutical industry. The aim of this study was to quantify by high pressure liquid chromatography (HPLC) the levels of diosgenin in a collection of seventy four tubers of $D$. polygonoides from different localities of the Eje Cafetero (EC, Colombia).

\section{Experimental}

\section{General experimental procedures}

The solvents $n$-hexane, chloroform, methanol, ethanol, $n$-butanol and acetonitrile used for the steroidal sapogenin extraction and analysis were purchased from Mallinckrodt (Phillipsburg, NJ, USA); diosgenin [CAS: 512-04-9] standard and the enzyme naringinase (E.C.: 232-962-4) were purchased from Sigma (St. Louis, MO, USA).

For diosgenin quantification a HPLC Hewlett Packard instrument model HP-1100 (Palo Alto, CA, USA) equipped with the software version ChemStation A.06.01, a diode array detector (DAD-UV) was used; in addition, a Hypersil ODS C18 column $(250 \times 4.0 \mathrm{~mm}, 5 \mu \mathrm{m})$ and a $20 \mu \mathrm{L}$ Rheodyne manual injector were used.

\section{Plant material}

Tubers of $D$. polygonoides were collected during the period between November 2002 and November 2003 at different zones in the EC. This area is constituted by the departments of Caldas, Quindío and Risaralda (Colombia), and they are located on the Central Andean mountain chain, with an extension area of $13.893 \mathrm{~km}^{2}$, with different altitudinal zones (900-5400 m) and high annual precipitation. Plant samples were authenticated by the authors, see Table 1 , and a voucher for a specimen was deposited at the Universidad de Antioquia Herbarium (Medellín, Colombia), under the code number HUA 132745.

\section{Diosgenin extraction}

Each collected tuber was washed, chopped to in fine slices and oven-dried at $50{ }^{\circ} \mathrm{C}$ to constant weight and ground to a fine powder, as described by Mahato et al. ${ }^{12}$ Next, for each colleted tuber $10.00 \mathrm{~g}$ aliquot were taken and defatted with $n$-hexane in a Soxhlet extractor. The degreased plant materials were extracted three times with methanol in Soxhlet, and the combined methanol extracts were concentrated to dryness at reduced pressure. After that, each methanol extract was resuspended in $10 \mathrm{~mL}$ of water HPLC grade and partitioned three times with portions of $6 \mathrm{~mL}$ of $n$-butanol saturated with water, to obtain the crude saponins ${ }^{13}$ Finally, $50 \mathrm{mg}$ of each butanol extract were hydrolyzed by treatment with the enzyme naringinase to obtain the crude sapogenins, following the procedure described by Niño et al. ${ }^{9}$

\section{Diosgenin quantification}

Diosgenin quantification was performed on a HPLC instrument applying the external standard method, through a diosgenin calibration curve with six points in a concentration range between $50-300 \mathrm{mg} \mathrm{L}^{-1}$. The experimental conditions were an isocratic binary system of acetonitrile/water (90:10), a flow rate of $1 \mathrm{~mL} \mathrm{~min}^{-1}$ and a temperature of $35^{\circ} \mathrm{C}$. Detection was performed at 194 $\mathrm{nm}$, according to the procedure described by Oncina et al. ${ }^{14}$

The diosgenin concentrations in the different samples were calculated through a regression analysis from the peak area and the known concentrations of authentic diosgenin samples and are the average of three consecutive readings for each tuber sample.

\section{Results and Discussion}

\section{Tuber collection}

Seventy four $D$. polygonoides tubers were collected at 10 different localities from the Eje Cafetero (EC) as showed in Table 1.

\section{Diosgenin quantification by HPLC}

The hydrolysis of the $n$-butanol extracts with the enzyme naringinase produced diosgenin as well as other sapogenins. The use of the enzyme hydrolysis reduced significantly diosgenin degradation as well as the production of artifacts and this might increase the diosgenin yields in this study. ${ }^{1,15}$ The diosgenin recovery using the method reported here was $97 \%$, which is higher than that obtained by the acid hydrolysis of $n$-butanol extracts from Trigonella foenum-graecum L. ${ }^{16}$

The experimental conditions used for diosgenin quantification by HPLC in the different $D$. polygonoides 
Table 1. Places and number of D. polygonoides tubers collected in the Eje Cafetero

\begin{tabular}{|c|c|c|}
\hline Recolection Places & Geographic Coordinates & Numer of Sample \\
\hline Salamina (Caldas) ${ }^{1}$ & $\begin{array}{c}\mathrm{N} 6^{\circ} 16^{\prime} 48^{\prime \prime} \\
\mathrm{W} 73^{\circ} 18^{\prime} 05^{\prime \prime}\end{array}$ & 1 to 7 \\
\hline Jardín Botánico UTP² (Risaralda) & $\begin{array}{c}\mathrm{N} 4^{\circ} 42^{\prime} 89^{\prime \prime} \\
\mathrm{W} 70^{\circ} 35^{\prime} 00^{\prime \prime}\end{array}$ & 8 to 10 \\
\hline Circasia (Quindío) & $\begin{array}{c}\mathrm{N} 6^{\circ} 5^{\prime} 37^{\prime \prime} \\
\mathrm{W} 74^{\circ} 5^{\prime} 46^{\prime \prime}\end{array}$ & 11 to 16 \\
\hline Parque Ucumarí (Risaralda) & $\begin{array}{c}\mathrm{N} 4^{\circ} 42^{\prime} 89^{\prime \prime} \\
\mathrm{W} 73^{\circ} 35^{\prime} 00^{\prime \prime}\end{array}$ & 17 to 27 \\
\hline Ecoparque LosYarumos (Caldas) & $\begin{array}{c}\mathrm{N} 6^{\circ} 11^{\prime} 40^{\prime \prime} \\
\mathrm{W} 73^{\circ} 35^{\prime} 55^{\prime \prime}\end{array}$ & 28 to 38 \\
\hline La Nona (Risaralda) & $\begin{array}{c}\mathrm{N} 5^{\circ} 58^{\prime} 41^{\prime \prime} \\
\mathrm{W} 73^{\circ} 48^{\prime} 06^{\prime \prime}\end{array}$ & 39 to 48 \\
\hline Salento (Quindío) & $\begin{array}{c}\text { N 6 } 12^{\circ} 48^{\prime \prime} \\
\text { W } 73^{\circ} 46^{\prime} 69^{\prime \prime}\end{array}$ & 49 to 52 , and 56 \\
\hline Valle del Cocora (Quindío) & $\begin{array}{c}\mathrm{N} 6^{\circ} 12^{\prime} 48^{\prime \prime} \\
\mathrm{W} 75^{\circ} 40^{\prime} 00^{\prime \prime}\end{array}$ & 53 to 55 \\
\hline Filandia (Quindío) & $\begin{array}{c}\mathrm{N} 6^{\circ} 0^{\prime} 10^{\prime \prime} \\
\mathrm{W} 173^{\circ} 59^{\prime} 40^{\prime \prime}\end{array}$ & 57 to 63 \\
\hline Alto del Nudo (Risaralda) & $\begin{array}{c}\text { N 5 } 55^{\circ} 93^{\prime \prime} \\
\text { W } 73^{\circ} 44^{\prime} 66^{\prime \prime}\end{array}$ & 64 to 74 \\
\hline
\end{tabular}

${ }^{1}$ Department where the collection took place; ${ }^{2} \mathrm{UTP}=$ Universidad Tecnológica de Pereira.

extracts gave a highly reproducible retention time $\left(\mathrm{t}_{\mathrm{R}}\right)$ equal to $11.8 \pm 0.05 \mathrm{~min}$. All samples studied gave the same chromatographic pattern. The diosgenin peak in gas chromatography-mass spectrometry (GC-MS) of some tuber extracts displayed similar fragmentation patterns as diosgenin standard (data not shown). In addition, they are in concordance with the information reported on steroidal sapogenins isolation by HPLC. ${ }^{17}$

The results of diosgenin quantification by HPLC are given in Figure 2. The percentages of diosgenin obtained from the seventy four accessions of $D$. polygonoides on this work are in the range from 0.02 to $2.64 \%$, which is significant since there are several literature data where the diosgenin contents are very low, for example: $D$. polygonoides $(0.2 \%) ;{ }^{3}$ Dioscorea althaeoides $(0.2-2.3 \%) ;{ }^{18}$ Dioscorea prazeri $(1.92 \%) ;{ }^{12}$ Dioscorea villosa $(1.3 \%) ;{ }^{19}$ 2 years old Dioscorea zingiberenzis $(0.18-0.55 \%),{ }^{20}$ several Dioscorea species (0.04-0.93\%), ${ }^{21}$ among others.

The tubers with the highest diosgenin contents were collected in Salamina (Caldas) and Salento (Quindío) (see Table 1). These towns are located on the Colombian Central Andes mountain chain with an altitude of 1820 and 1920 meters above the sea level, respectively. Both places have an average temperature of $15^{\circ} \mathrm{C}$ and an annual precipitation of $3000 \mathrm{~mm}$ per year. In both localities there is a predominance of volcanic soils ( $\mathrm{pH} 4.0-7.0)$. However, these two localities are far away and there is not a connection between them. One possibility that can arise to explain the

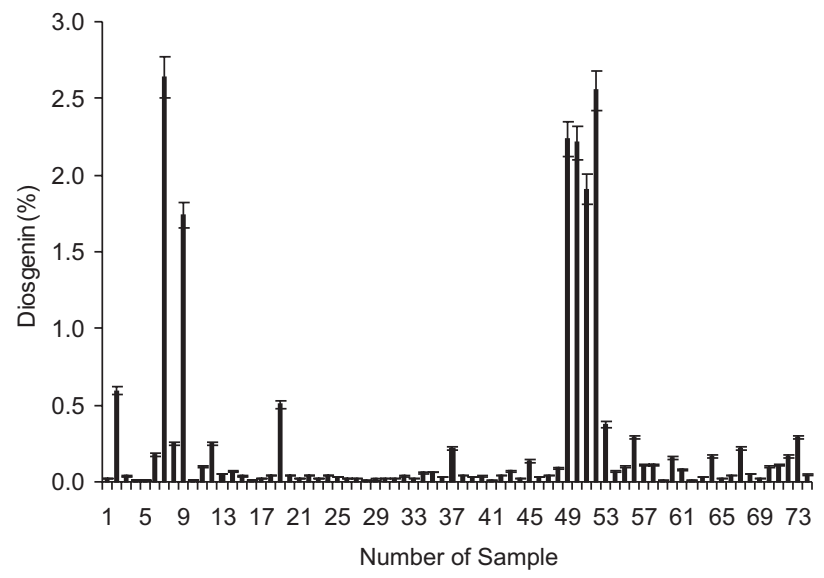

Figure 2. Diosgenin percentage on dry base, for each one of the seventy four D. polygonoides tubers collected in the Eje Cafetero.

reason why the tubers from this region gave the highest diosgenin yields is that they would be genetically close to the other ones, due to its anemochorous dispersion at some time, facilitated by the membranous wing around their seeds and by human factors; these aspects could promote the spread and distribution of $D$. polygonoides populations in these two localities. ${ }^{22}$ Another possibility is that the screening was done on tubers with different weights, and consequently they had different ages. In the study of Chapagain and Wiesman ${ }^{11}$ they found that two years old tubers gave higher diosgenin contents than those one year old, these results are not in concordance with the ones found in this work, since there was not a correlation between the 
weight of the tubers collected and their diosgenin production (data not shown).

Furthermore, the heterogeneity found on the steroidal sapogenin contents from the different $D$. polygonoides accessions analyzed in this study might depend on factors such as the genotype, the physiological state, the climatic conditions as well as the geographic localization of plants as pointed out by Dinan et al. ${ }^{1}$ These findings correlate with the determination of the steroidal sapogenin contents in different Tribulus terristris samples by HPLC, where significant differences were found depending on the origin and part of the plant used for extraction..$^{16,23}$

\section{Conclusions}

The D. polygonoides tubers collected in the Eje Cafetero (EC, Colombia), showed a wide range of diosgenin contents. As four of the seventy four tuber collected in the EC showed a diosgenin content higher than $2 \%$ on dry base, showing that the tubers of $D$. polygonoides could be a new source of diosgenin supply. Further studies looking for high yielding varieties and the effect of environmental factors on diosgenin levels could be required to develop a high diosgenin producing variety.

\section{Acknowledgments}

The authors gratefully acknowledge the financial support of the Universidad Tecnológica de Pereira (UTP) to this research project. We thank also the directors of CARDER and Ecoparque Los Yarumos, for granting the permissions to collect the different plant materials used in this work.

\section{References}

1. Dinan, L.; Harmatha, J.; Lafont, R.; J Chromatogr. A 2001, 935, 105.
2. Caddick, L. R.; Wilkin, P.; Rudall, P. J.; Hedderson, T. A. J.; Chase, M. W.; Taxon 2002, 51, 103.

3. Coursey, D. G.; Yams: An Account of the Nature, Origins, Cultivation and Utilization of the Useful Members of the Dioscoreaceae; Longmans: London, 1967.

4. Degras, L.; The Yams A Tropical Root Crop; MacMillan Press Ltda: London, 1993.

5. Jefferies, T.; Hardman, R.; Planta Med. 1972, 22, 78.

6. Brenac, P.; Sauvaire, Y.; Phytochemistry 1996, 41, 415.

7. Sparg, S. G.; Light, M. E.; van Staden, J.; J. Ethnopharmacol. 2004, 94, 219.

8. Burkill, I. H.; J. Linn. Soc. Bot. 1960, 56, 319.

9. Niño, J.; Mosquera, O.; Correa, Y.; Mimaki, Y.; Sakagami, H.; Sashida, Y.; Heterocycles 2003, 60, 1709.

10. Niño, J.; Mosquera, O.; Correa, Y.; Wanatabe, K.; Sakagami, H.; Mimaki, Y.; J. Nat. Prod. 2005, 68, 1116.

11. Chapagain, B.; Wiesman, Z.; Afri. J. Biotechnol. 2005, 4, 1209.

12. Mahato, S. B.; Sahu, N. P.; Roy, S. K.; J. Chromatogr. 1981, 206, 169.

13. Mimaki, Y.; Wanatabe, K.; Sakuma, C.; Sakagami, H; Sashida, Y.; Helv. Chim. Acta 2003, 86, 398.

14. Oncina, R.; Botía, J.; Del Río, J.; Ortuño, A.; Food Chem. 2000, $70,489$.

15. Taylor, W.; Zulyniak, H.; Richards, K.; Acharya, S.; Bittman, S.; Elder, J.; J. Agric. Food Chem. 2002, 50, 5994.

16. Oleszek, W.; J. Chromatogr. A 2002, 967, 147.

17. Lin, J-T.; Xu, C-J.; J. Chromatogr. 1984, 287, 105.

18. Chen, Y.; Wu, Y.; J. Herbs, Spices Med. Plants 1994, $2,59$.

19. Martin, F. W.; Econ. Bot. 1969, 23, 373.

20. Li, H.; Radunz, A.; He, P.; Schmid, G.H.; Z. Naturforsch., C: J. Biosci. 2002, 57c, 135.

21. Vendl, O.; Wawrosch, C.; Noe, C.; Molina, C.; Kahl, G.; Koopp, B.; Z. Naturforsch., C: J. Biosci. 2006, 61c, 847.

22. Niño, J.; Díez, M.J.; Nuez, F.; J. Hort. Sci. Biotechnol. 2006, $81,803$.

23. Ganzera, M.; Bedir, E.; Khan, I. A.; J. Pharm. Sci. 2001, 90, 1752.

Received: September 11, 2006

Web Release Date: August 6, 2007 